\title{
In vitro antiviral activity of twenty-seven medicinal plant extracts from Southwest Nigeria against three serotypes of echoviruses
}

Omonike O. Ogbole ${ }^{1^{*}}$ D, Toluwanimi E. Akinleye ${ }^{1}$, Peter A. Segun ${ }^{2}$, Temitope C. Faleye ${ }^{3}$ and Adekunle J. Adeniji ${ }^{4}$

\begin{abstract}
Background: Echoviruses, a serotype of enteroviruses, infect millions of people globally and there is no specific drug treatment or vaccine available for its management. The screening of medicinal plants used locally for the treatment of infectious diseases, can provide a reliable option in the discovery of potent therapeutic compounds. This study was carried out to investigate the antiviral activities of 27 medicinal plant extracts, belonging to 26 different plant species, selected from Nigerian ethnobotany, against echovirus 7, 13 and 19 serotypes (E7, E13 and E19, respectively).
\end{abstract}

Methods: The plants were macerated in methanol and the cytotoxicities of the crude extracts were evaluated on the rhabdomyosarcoma cell line using the MTT assay. The antiviral activity of the plant extracts and fractions against echoviruses (E7, E13, and E19) was determined using the neutralisation assay, an assay that measures the inhibition of cytopathic effect on cell culture.

Results: The crude extract of Macaranga barteri leaves had the highest cytotoxicity with $\mathrm{CC}_{50}$ value of $0.27 \mu \mathrm{g} / \mathrm{mL}$. This was followed by Crinum jagus $(9.88 \mu \mathrm{g} / \mathrm{mL})$ and Terminalia ivorensis $(12.14 \mu \mathrm{g} / \mathrm{mL})$. The antiviral screening showed that ten out of the 27 crude plant extracts tested were active on E7 and E19, inhibiting the cytopathic effect of the virus in tissue culture. None of the extracts inhibited the cytopathic effect caused by E13 serotype. Amongst the active plant extracts, the methanol extract of $M$. barteri leaves had the highest antiviral activity on both $E 7$ and $E 9$ with $\mathrm{IC}_{50}$ values of 0.028 and $0.0017 \mathrm{ng} / \mathrm{mL}$, respectively, followed by the Ageratum conyzoides extract $(0.208 \mu \mathrm{g} / \mathrm{mL}, \mathrm{E} 7 ; 0.006 \mu \mathrm{g} / \mathrm{mL}$, E19) and Mondia whitei extract $(0.038 \mu \mathrm{g} / \mathrm{mL}$, E7; $0.005 \mu \mathrm{g} / \mathrm{mL}$, E19). Amongst the fractions of M. barteri, the DCM fraction was most the active and selective on $E 7\left(I C_{50}=0.0075 \mathrm{ng} / \mathrm{mL} ; \mathrm{SI}=19,896.54\right)$ and $\mathrm{E} 19\left(\mid \mathrm{C}_{50}=0.0175 \mathrm{ng} / \mathrm{mL} ; \mathrm{SI}=8581.24\right)$.

Conclusion: Our research has demonstrated that Macaranga barteri extracts has potent antiviral activity against echoviruses E7 and E19, and our findings suggest that this extract may have potential as a therapeutic agent in the treatment of enteroviral infections.

Keywords: Antiviral activity, Cytopathic effect inhibition, Echoviruses, Macaranga barteri, Nigerian plants

\footnotetext{
*Correspondence: nikeoa@yahoo.com

'Department of Pharmacognosy, Faculty of Pharmacy, University of Ibadan,

Ibadan, Nigeria

Full list of author information is available at the end of the article
}

(c) The Author(s). 2018 Open Access This article is distributed under the terms of the Creative Commons Attribution 4.0 International License (http://creativecommons.org/licenses/by/4.0/), which permits unrestricted use, distribution, and reproduction in any medium, provided you give appropriate credit to the original author(s) and the source, provide a link to the Creative Commons license, and indicate if changes were made. The Creative Commons Public Domain Dedication waiver (http://creativecommons.org/publicdomain/zero/1.0/) applies to the data made available in this article, unless otherwise stated. 


\section{Background}

The use of traditional medicine is popular in Africa, with almost three-quarter of the populace of this continent consulting traditional medical practitioners (TMPs), mainly traditional doctors, when faced with a medical problem. This is mainly because traditional healthcare system is easily accessible, culturally acceptable and comparatively cheaper to the costly orthodox medicine. In Nigeria and most developing countries, medicinal plants are traditionally used to treat a variety of ailments, especially infectious diseases [1].

Although medicinal plants have been widely regarded as a constant source of safe and effective medicines with potential to yield newer drugs, this potential is under threat due to the alarming biodiversity loss, with recent estimates indicating that every fifth plant species on earth is threatened with extinction [2]. Hence, scientists in drug discovery are making urgent effort to document and research into bioactivity of medicinal plants used in various ethnobotany, in order to establish correlation between the ethnomedical usage of medicinal plants and drug discovery in modern medicines [3, 4].

Enteroviruses (EVs) are single positive-stranded genomic RNA viruses of the family Picornaviridae that consists of more than 100 serotypes. They have emerged as one of the important etiological agents for encephalitis, especially in children and adults. For instance, enteroviruses such as coxsackievirus A9, A10 and B5; echoviruses 4, 5, 9, 11, 19 and 30; and EV 71, 75, 76 and 89, from various parts of the world have been reported in encephalitis cases and epidemics [5]. Echoviruses (enteric cytopathic human orphan viruses) are small ( $300 \AA$ in diameter - $27 \mathrm{~nm})$, non-enveloped icosahedral viruses which belong to enterovirus species B of the family Picornaviridae with 29 serotypes (E1-E29). The most frequent clinical diseases of echoviruses include fever of short duration and sometimes a rash or mild upper respiratory symptoms [6]. Clinical syndromes associated with infections by echoviruses include aseptic meningitis, paralysis, encephalitis, ataxia, Guillain-Barré syndrome, exanthema, respiratory disease, diarrhoea, pericarditis, myocarditis and hepatic disturbance. Echoviral infection, like other enteroviruses, occurs via faecal-oral route transmission [7].

There is no specific drug treatment in clinical use available for enteroviruses, and at the moment, development of vaccine against all EVs is not feasible due to the great number of serotypes $[8,9]$. Added to this is the general problem of viral resistance towards antiviral agents, especially RNA viruses, which can mutate at high frequencies and evolve rapidly into drug-resistant strains [10]. Therefore, the increasing need for search of new effective compounds with anti-enteroviral activity is imperative. Natural products from medicinal plants have proved to be effective against a wide variety of viral diseases by inhibiting the replication cycle of various DNA and RNA viruses [11]. This validated the use of plant-based antivirals as an integral part of many traditional systems of medicine [12]. Therefore, this work aimed at determining the antiviral activities of 27 plant extracts against echovirus 7, 13 and 19 serotypes.

\section{Methods}

\section{Plant materials and extraction}

Twenty-seven different morphological parts from 26 plants (Table 1), selected based on their ethnobotanical use in the treatment of infectious diseases, were collected from various locations in Ibadan, South-west Nigeria, identified and authenticated at Forestry Herbarium Ibadan (FHI). Plant parts used were air-dried, pulverized and extracted by maceration in methanol for $72 \mathrm{~h}$ at room temperature $\left(26-33{ }^{\circ} \mathrm{C}\right)$. The resulting extracts were filtered and concentrated in vacuo using the rotary evaporator.

\section{Fractionation of the active extract}

The most active crude extract (Macaranga barteri) was subjected to bioassay guided fractionation using liquid-liquid partitioning and vacuum liquid chromatography (VLC). Briefly, $150 \mathrm{~g}$ of the crude methanol extract of $M$. barteri was dissolved in $250 \mathrm{~mL}$ of $70 \%$ aqueous methanol and the mixture was partitioned successively in $n$-hexane $(400 \mathrm{~mL} \times 4)$, dichloromethane (DCM; $400 \mathrm{~mL} \times 4)$, ethylacetate (EtOAc; $400 \mathrm{~mL} \times 4$ ) and aqueous methanol $(400 \mathrm{~mL} \times 4)$. As the DCM fraction displayed the highest antiviral activity, it was subjected to vacuum liquid chromatography (VLC) on silica gel using a gradient elution solvent system that comprised of $n$-hexane/EtOAc (10:1 to $5: 5$, each $250 \mathrm{~mL}$ ). Based on the similarity of their analytical TLC profiles, the fractions obtained were pooled into six sub-fractions (DCMA - DCMF). The VLC fractions were sprayed with chromogenic spray reagents including $1 \%$ vanillin/sulphuric acid and aluminium chloride $\left(\mathrm{AlCl}_{3}\right)$ to detect the classes of possible compounds present.

\section{Viruses and cell line}

Three serotypes of echovirus (E7, E13, and E19) used in this study were obtained from stool isolate at the WHO Polio Laboratory, Department of Virology, University of Ibadan, Nigeria. All viruses were stored at $-70{ }^{\circ} \mathrm{C}$ until use. The human rhabdomyosarcoma (RD) cells were obtained by Centre for Disease Control, Atlanta, Georgia. The cells were grown in Eagle's minimum essential medium (MEM; Sigma-Aldrich) supplemented with 10\% fetal bovine serum (FBS), 100 units $/ \mathrm{mL}$ of penicillin, $100 \mu \mathrm{g} / \mathrm{mL}$ of streptomycin, $2 \mathrm{mM} \mathrm{L}$-glutamine, $0.07 \%$ $\mathrm{NaHCO}_{3}, 1 \%$ non-essential amino acids and vitamin solution. The cells were cultured in $37{ }^{\circ} \mathrm{C}$ in $5 \% \mathrm{CO}_{2}$ 
Table 1 Plant species analysed for antiviral activity

\begin{tabular}{|c|c|c|c|c|c|c|c|}
\hline $\mathrm{S} / \mathrm{N}$ & Family & Name & $\begin{array}{l}\text { Local Name } \\
\text { (Yoruba) }\end{array}$ & $\begin{array}{l}\text { Part } \\
\text { Used }\end{array}$ & $\begin{array}{l}\text { Voucher } \\
\text { (FHI) No }\end{array}$ & $\begin{array}{l}\text { MNTC } \\
(\mu \mathrm{g} / \mathrm{mL})\end{array}$ & Ethnomedicinal uses \\
\hline 1 & Amaryllidaceae & $\begin{array}{l}\text { Crinum jagus (J. Thomps.) } \\
\text { Dandy }\end{array}$ & Isu-meri & bu & 109011 & 10 & $\begin{array}{l}\text { Tuberculosis, epilepsy, asthma, infections, anti-snake } \\
\text { venom and sickle cell diseases [24]. }\end{array}$ \\
\hline 2 & Anacardiaceae & Spondias mombin $\mathrm{L}$. & lyeye & । & 108861 & 10 & $\begin{array}{l}\text { Stomach ache, abdominal discomfort, diabetes, wound } \\
\text { healing, haemorrhoids and vermifuge [25]. }\end{array}$ \\
\hline 3 & Anacardiaceae & Spondias mombin L. & lyeye & ba & 108861 & 10 & $\begin{array}{l}\text { Stomach ache, abdominal discomfort, diabetes, wound } \\
\text { healing, haemorrhoids and vermifuge [25]. }\end{array}$ \\
\hline 4 & Apocynaceae & $\begin{array}{l}\text { Picralima nitida (Stapf) T. } \\
\text { Durand \& H. Durand }\end{array}$ & Abeere & s & 108794 & 1 & $\begin{array}{l}\text { Hypertension, fever, jaundice, dysmenorrhea, malaria and } \\
\text { abdominal discomfort [26]. }\end{array}$ \\
\hline 5 & Asclepiadaceae & $\begin{array}{l}\text { Secamone afzelii (Roem et } \\
\text { Schult) K. Schum }\end{array}$ & Ailu & । & 109995 & 1 & Diabetes, colic, dysentery, hypertension and malaria [27]. \\
\hline 6 & Asteraceae & Ageratum conyzoides L. & Imi-esu & । & 106040 & 100 & $\begin{array}{l}\text { Purgative, ulcers, mental illness, infections, skin diseases, } \\
\text { wound healing, febrifuge, pneumonia, toothache and } \\
\text { rheumatism [28]. }\end{array}$ \\
\hline 7 & Boraginaceae & Heliotropium indicum L. & Apari-igun & । & 110156 & 10 & $\begin{array}{l}\text { Wounds, flatulence, inflammation, skin ulcers and } \\
\text { conjunctivitis [29]. }\end{array}$ \\
\hline 8 & Combretaceae & Terminalia ivorensis A. Chev. & Afara-dudu & ba & 105432 & 1 & Syphilis, burns, bruises, arthritis and haemorrhoids [30]. \\
\hline 9 & Combretaceae & $\begin{array}{l}\text { Terminalia superba Engl. } \\
\text { \& Diels. }\end{array}$ & Afara-funfun & ba & 109800 & 1 & Diabetes, skin infections, leg ulcers and cancers [31]. \\
\hline 10 & Convolvulaceae & $\begin{array}{l}\text { Ipomoea asarifolia (Desr.) } \\
\text { Roem. \& Schult. }\end{array}$ & Gboro-ayaba & । & 110052 & 1 & Skin infections, abdominal cramps and diarrhoea [32]. \\
\hline 11 & Crassulaceae & $\begin{array}{l}\text { Bryophyllum pinnatum } \\
\text { (Lam.) Oken }\end{array}$ & Abamoda & । & 109487 & 100 & $\begin{array}{l}\text { Worm expellant, cold, pneumonia and respiratory tract } \\
\text { infections [33]. }\end{array}$ \\
\hline 12 & Cucurbitaceae & $\begin{array}{l}\text { Lagenaria breviflora } \\
\text { (Benth.) Roberty }\end{array}$ & Tagiri & s & 109040 & 1 & $\begin{array}{l}\text { Female infertility, measles, chicken pox and skin } \\
\text { infections [34]. }\end{array}$ \\
\hline 13 & Dilieniaceae & Tetracera alnifolia Willd. & Opon & । & 107511 & 10 & Constipation, cancer, leprosy, toothache and cough [35]. \\
\hline 14 & Euphorbiaceae & Croton gratissimus Burch. & Ajekobale & । & 109041 & 1 & $\begin{array}{l}\text { Coughs, bleeding gums, eye disorders, influenza, fever, } \\
\text { malaria, skin infections [36]. }\end{array}$ \\
\hline 15 & Euphorbiaceae & $\begin{array}{l}\text { Macaranga barteri } \\
\text { Mull. Arg. }\end{array}$ & Agbaasa & I & 107230 & 0.01 & $\begin{array}{l}\text { Gonorrhoea, syphilis, skin infections, cancer and } \\
\text { burns [37]. }\end{array}$ \\
\hline 16 & Lamiaceae & Hoslundia opposita Vahl & Efirin-odan & I & 100866 & 10 & Burns, skin infections, cough and malaria [38]. \\
\hline 17 & Leguminosae & $\begin{array}{l}\text { Calliandra portoricensis } \\
\text { (Jacq.) Benth }\end{array}$ & Tude & r & 109672 & 0.1 & $\begin{array}{l}\text { Prostate cancer, inflammations, cough and } \\
\text { haemorrhoids [39]. }\end{array}$ \\
\hline 18 & Meliaceae & $\begin{array}{l}\text { Entandrophragma utile } \\
\text { (Dawe \& Sprague) Sprague }\end{array}$ & Jebo & $\mathrm{ba}$ & 86848 & 1 & leg ulcer, anthelmintic, wound, abdominal pain [40]. \\
\hline 19 & Mimosaceae & Mimosa pudica $\mathrm{L}$. & Patanmo & । & 100332 & 0.1 & Fevers, piles, jaundice, leprosy and dysentery [41]. \\
\hline 20 & Nyctaginaceae & Boerhavia diffusa $\mathrm{L}$. & Etipase-erinla & r & 109603 & 1 & $\begin{array}{l}\text { Diabetes, cancer, inflammation, infections and } \\
\text { epilepsy [42]. }\end{array}$ \\
\hline 21 & Periplocaceae & $\begin{array}{l}\text { Mondia whitei (Hook.f.) } \\
\text { Skeels }\end{array}$ & Isirigun & । & 110043 & 100 & Malaria, diabetes, infertility and erectile dysfunction [43]. \\
\hline 22 & Periplocaceae & $\begin{array}{l}\text { Parquentina nigrescens } \\
\text { (Afzel) Bullock }\end{array}$ & Ogbo & । & 108852 & 1 & Abdominal cramps, gonorrhoea, rickets and asthma [44]. \\
\hline 23 & Phytolaccaceae & Petiveria alliacea L. & Awogba & । & 100512 & 100 & $\begin{array}{l}\text { Pain, influenza, cold, diabetes, malaria and skin } \\
\text { infections [45]. }\end{array}$ \\
\hline 24 & Piperaceae & Piper guineensis Schumach & lyere & I & 110051 & 10 & $\begin{array}{l}\text { Sickle cell anaemia, male infertility, inflammation } \\
\text { and skin infections [46]. }\end{array}$ \\
\hline 25 & Poaceae & Eleusine indica (L.) Gaertn. & Gbegi & I & 92140 & 1 & Diabetes, anthelminthic, cough and wound [47]. \\
\hline 26 & Rubiaceae & $\begin{array}{l}\text { Sarcocephalus latifolius (Sm.) } \\
\text { E. A. Bruce }\end{array}$ & Egbesi & I & 109707 & 10 & Epilepsy, diarrhoea, dysentery, malaria and fever [48]. \\
\hline 27 & Verbenaceae & Lippia multiflora Moldenke & Eforomoba & I & 108858 & 10 & $\begin{array}{l}\text { Fever, constipation, ear infections, eye troubles, and } \\
\text { diabetes [49]. }\end{array}$ \\
\hline
\end{tabular}


humidified incubator for $72 \mathrm{~h}$. The test medium used for cytotoxic assays and antiviral assays contained only $2 \%$ of fetal bovine serum (maintenance medium).

\section{Preparation of stock solution of extract and fraction}

Crude extracts and fractions, $10 \mathrm{mg}$ each were dissolved in $1 \mathrm{~mL}$ dimethlysulfoxide (DMSO) and filtered through a sterile syringe filter $(0.2 \mu \mathrm{m}$ pore diameter $)$ to obtain a stock solution (SS; $10 \mathrm{mg} / \mathrm{mL}$ ). The SS was diluted with the maintenance medium (culture medium that contained only $2 \%$ FBS) to obtain a final concentration of $1000 \mu \mathrm{g} / \mathrm{mL}(0.1 \% \mathrm{DMSO})$.

\section{Tissue culture infective dose (TCID)}

Virus titres were determined by virus-induced cytopathic effect in RD cell culture and were expressed as 50\% tissue culture infective concentration $\left(\mathrm{TCID}_{50}\right)$ per $\mathrm{mL}$ using Sperman-Karber's method. Briefly, RD cells were seeded into T25 cell culture flask (Corning ${ }^{\circ}, \mathrm{UK}$ ), and incubated at $37{ }^{\circ} \mathrm{C} / 5 \% \mathrm{CO}_{2}$ environment for $24 \mathrm{~h}$. Thereafter, $100 \mu \mathrm{L}$ of E7 were incorporated into the T25 flask containing the cultured RD cells and incubated for $72 \mathrm{~h}$, leading to an increment in the virus stock quantity as a result of the $100 \%$ cytopathic effect. One hundred microliters $\mathrm{RD}$ cell suspension $\left(1 \times 10^{6}\right.$ cells $\left./ \mathrm{mL}\right)$ was seeded into three 96-well microtitre plates and incubated for $24 \mathrm{~h}$ to form monolayer. Ten-fold serial dilutions of the virus stock was made and $100 \mu \mathrm{L}$ of each dilution was inoculated into the wells. A well that contained only $\mathrm{RD}$ cells without any virus served as the cell control. The microtitre plate was incubated at $37{ }^{\circ} \mathrm{C}$, and daily CPE scoring was done till the control wells started dying. The $\mathrm{TCID}_{50}$ values was determined using Spearman-Karber's method and $100 \mathrm{TCID}_{50}$ was used for the assay. The procedure was done in triplicate and repeated for the E13 and E19.

\section{Cytotoxicity assay}

The MTT (3-(4,5-dimethythiazol-2-yl)-2,5-diphenyl tetrazolium bromide) colorimetric assay, which is known to be a reliable measure of cell viability, was used to determine the cytotoxicity of the plant extracts and fractions. The principle of this assay involves the reduction of yellow MTT dye by mitochondrial succinate dehydrogenase to an insoluble, coloured (dark purple) formazan product. The purple formazan-containing cells are then solubilized with an organic solvent such as DMSO to release the solubilized formazan reagent which is measured by spectrophotometry. The assay was carried out based on the protocol described in an earlier literature [13]. In brief, ten-fold serial dilutions (1000 to $0.01 \mu \mathrm{g} / \mathrm{mL}$ ) of the extracts / fractions were made with the maintenance. Monolayers of RD cells were seeded into each well of a 96-well microplate and treated with various concentrations of each extract/fraction. Plates were incubated at $37{ }^{\circ} \mathrm{C}$ in $5 \% \mathrm{CO}_{2}$ humidified incubator for $72 \mathrm{~h}$. Plates were then observed under the microscope for cell death/cytopathic effect (CPE). The minimum dilution of extract with no toxic effect on the cells was referred to as the maximum non-toxic concentration (MNTC). After the incubation period, the old medium was removed and $25 \mu \mathrm{L}$ of MTT solution $(2 \mathrm{mg} / \mathrm{mL})$ was added to each well and incubated for $2 \mathrm{~h}$ at $37{ }^{\circ} \mathrm{C}$. thereafter, the MTT solution was removed from the wells and DMSO $(75 \mu \mathrm{L})$ was added to dissolve formazan crystal. Optical density was measured spectrophotometrically (Multiscan 347, MTX lab) at $490 \mathrm{~nm}$. The experiment was conducted in triplicate and the $50 \%$ cytotoxic concentration $\left(\mathrm{CC}_{50}\right)$ was calculated.

\section{Antiviral activity assay}

The antiviral activity of the plant extracts and fractions against echoviruses (E7, E13, and E19) was determined using the neutralisation assay, an assay that measures the inhibition of cytopathic effect on cell culture. The method previously described in the literature was modified and used in this assay [14]. Briefly, RD cells were seeded in a 96-well microplate and incubated for $24 \mathrm{~h}$ to grow to confluency. After the incubation period, $50 \mu \mathrm{L}$ of 100 $\mathrm{TCID}_{50}$ virus suspension were added to confluent cell monolayers in a 96-well plate and allowed to stand for $1 \mathrm{~h}$ to enable virus adsorption. Thereafter, ten-fold serial dilutions, obtained from the MNTC of each extract were added in triplicate into all the wells with the exception of the negative control wells that contained only RD cells and the virus control that contained an equal virus concentration but lacked the plant extract. The plates were incubated at $37{ }^{\circ} \mathrm{C}$ in $5 \% \mathrm{CO}_{2}$ humidified incubator for $72 \mathrm{~h}$ after which the cell viability was measured using the MTT assay as described above. The concentration of the plant extract that decreased the CPE by $50 \%$, with respect to the virus control, was estimated from the obtained optical density and defined as the 50\% inhibition concentration $\left(\mathrm{IC}_{50}\right)$. The selectivity index (SI), defined as $\mathrm{CC}_{50}$ over $\mathrm{IC}_{50}$, for each active extract and fractions were also determined. Since there are no antiviral drugs approved for the treatment of enteroviral infections, no drug control was used in this study. All experiments were carried out in triplicates.

\section{Data analysis}

The experiments were conducted in triplicate. The 50\% cytotoxic concentration $\left(\mathrm{CC}_{50}\right)$ and the $50 \%$ inhibitory concentration $\left(\mathrm{IC}_{50}\right)$ for the extracts and fractions were calculated from concentration-effect-curves after linear regression analysis using GraphPad Prism5 and Microsoft Excel. The selectivity index for each active extract and fractions were also determined. Selective index is a 
comparison of the amount of a test agent that causes the inhibitory effect to the amount that causes toxicity.

\section{Results}

Tissue culture infective dose

The determination of the virus titre $\left(\mathrm{TCID}_{50}\right)$ for $\mathrm{E} 7$, E13, and E19 viruses by Sperman-Karber's method gave a value of $10^{-6}$ for the three viruses. Therefore, $100 \mathrm{TCID}_{50}$ which was used for the study was calculated as $10^{-4}$.

\section{Maximum non-toxic concentration (MNTC) of crude extracts}

The plant extracts encountered in this study displayed varying MNTC to RD cells in tissue culture medium. As presented in Table 1, the extract of Macaranga barteri leaves had the lowest MNTC $(0.01 \mu \mathrm{g} / \mathrm{mL})$, while Petiveria alliacea, Mondia whitei, Ageratum conyzoides and Bryophyllum pinnatum extracts had the highest MNTC of $100 \mu \mathrm{g} / \mathrm{mL}$.

\section{Cytotoxic activities of plant extracts and fractions}

As presented in Table 2, the cytotoxic concentration that inhibited $50 \%$ of cell growth $\left(\mathrm{CC}_{50}\right)$ showed that the crude extract of $M$. barteri leaves had the highest cytotoxicity with $\mathrm{CC}_{50}$ value of $0.27 \mu \mathrm{g} / \mathrm{mL}$. This was followed by Crinum jagus $(9.88 \mu \mathrm{g} / \mathrm{mL})$ and Terminalia ivorensis $(12.14 \mu \mathrm{g} / \mathrm{mL})$. The DCM fraction of M. barteri showed the highest cytotoxicity amongst the fractions with $\mathrm{CC}_{50}$ value of $0.18 \mu \mathrm{g} / \mathrm{mL}$. Other fractions including $n$-hexane, ethyl acetate and aqueous had $\mathrm{CC}_{50}$ values of 24.9, 2.87 and $3.01 \mu \mathrm{g} / \mathrm{mL}$, respectively. Amongst the VLC sub-fractions of $M$. barteri, sub-fraction A (DCMA) displayed the highest cytotoxicity on the RD cells with $\mathrm{CC}_{50}$ value of $0.47 \mu \mathrm{g} / \mathrm{mL}$ (Table 3).

\section{Antiviral screening of plant extracts and fractions}

The preliminary antiviral screening showed that only ten out of the 27 crude plant extracts tested were active on E7 and E19, inhibiting the cytopathic effect of the virus in tissue culture (Table 2). On E7, M. barteri displayed $75 \%$ CPE inhibition at MNTC $(0.01 \mu \mathrm{g} / \mathrm{mL}), 50 \%$ inhibition at $0.001 \mu \mathrm{g} / \mathrm{mL}$, while the extract exhibited $75 \%$ CPE inhibition at MNTC $(0.01 \mu \mathrm{g} / \mathrm{mL})$ and 50\% CPE inhibition at $0.01 \mathrm{ng} / \mathrm{mL}$ on E19. None of the extracts inhibited the cytopathic effect caused by E13 serotype. Amongst the active plant extracts, the crude methanol extract of $M$. barteri leaves had the highest antiviral activity on both $\mathrm{E} 7$ and $\mathrm{E} 9$ with $\mathrm{IC}_{50}$ values of 0.028 and $0.0017 \mathrm{ng} / \mathrm{mL}$, respectively, followed by the Ageratum conyzoides extracts $(0.208 \mu \mathrm{g} / \mathrm{mL}, \mathrm{E} 7 ; 0.006 \mu \mathrm{g} / \mathrm{mL}, \mathrm{E} 19)$ and Mondia whitei extracts $(0.038 \mu \mathrm{g} / \mathrm{mL}, \mathrm{E} 7 ; 0.005 \mu \mathrm{g} /$ $\mathrm{mL}, \mathrm{E19}$ ) (Table 2). Amongst the liquid-liquid partitioned fractions of $M$. barteri, the DCM was most the active and selective on E7 $\left(\mathrm{IC}_{50}=0.0075 \mathrm{ng} / \mathrm{mL} ; \mathrm{SI}=19,896.54\right)$ and E19 $\left(\mathrm{IC}_{50}=0.0175 \mathrm{ng} / \mathrm{mL} ; \mathrm{SI}=8581.24\right)$ when compared with the hexane fraction which had moderate activity on E7 $\left(\mathrm{IC}_{50}=0.442 \mu \mathrm{g} / \mathrm{mL} ; \mathrm{SI}=57.96\right)$ and E19 $\left(\mathrm{IC}_{50}=\right.$ $0.305 \mu \mathrm{g} / \mathrm{mL} ; \mathrm{SI}=83.85)$. However, both the ethyl acetate and aqueous fractions of $M$. barteri were inactive against E7 and E19. In addition, sub-fraction D (DCMD) displayed the highest antiviral activity amongst the sub-fractions on both E7 $\left(\mathrm{IC}_{50}=0.00477 \mu \mathrm{g} / \mathrm{mL}\right)$, and E19 $\left(\mathrm{IC}_{50}=0.00532 \mu \mathrm{g} / \mathrm{mL}\right)$ (Table 3).

\section{Detection of compounds in the active M. barteri sub- fraction}

Yellow colouration and mint green spots were observed when sub-fraction D (DCMD) was sprayed with vanillin/ sulphuric acid. In addition, yellow spots were observed at short $(254 \mathrm{~nm})$ and long $(365 \mathrm{~nm})$ wavelengths of UV light when the sub-fraction was sprayed with aluminium chloride.

Table 2 Anti-echovirus activity of crude methanol extracts

\begin{tabular}{|c|c|c|c|c|c|c|c|}
\hline \multirow[t]{2}{*}{$\mathrm{S} / \mathrm{N}$} & \multirow[t]{2}{*}{ Plant } & \multirow{2}{*}{$\begin{array}{l}\mathrm{CC}_{50} \\
(\mu \mathrm{g} / \mathrm{mL})\end{array}$} & \multicolumn{3}{|c|}{$\mathrm{I}_{50}(\mu \mathrm{g} / \mathrm{mL})$} & \multicolumn{2}{|l|}{$\mathrm{SI}$} \\
\hline & & & E7 & E13 & E19 & E7 & E19 \\
\hline 1 & Ageratum conyzoides & 155.33 & $2.08^{*} 10^{-3}$ & NA & $5.64^{*} 10^{-4}$ & 746.78 & $2.80^{*} 10^{4}$ \\
\hline 2 & Bryophyllum pinnatum & 125.47 & 3.13 & NA & 2.03 & 40.07 & 61.96 \\
\hline 3 & Crinum jagus & 9.88 & 0.21 & NA & 1.94 & 46.65 & 5.09 \\
\hline 4 & Ipomoea asarifolia & 84.21 & $2.52^{*} 10^{-3}$ & NA & NA & 35,004 & - \\
\hline 5 & Lippia multiflora & 112.07 & 1.532 & NA & NA & 73.15 & - \\
\hline 6 & Macaranga barteri & 0.27 & $2.76^{*} 10^{-5}$ & NA & $1.69^{*} 10^{-6}$ & 7971.00 & $1.30^{*} 10^{5}$ \\
\hline 7 & Mondia whitei & 132.50 & 0.04 & NA & $5.35^{*} 10^{-4}$ & 3447.83 & $2.4^{*} 10^{4}$ \\
\hline 8 & Spondias mombin ${ }^{\mathrm{a}}$ & 53.33 & 0.10 & NA & NA & 512.3 & NA \\
\hline 9 & Terminalia ivorensis & 12.14 & 0.01 & NA & NA & 1213.4 & NA \\
\hline 10 & Tetracera alnifolia & 147.8 & 1.61 & NA & NA & 91.7 & NA \\
\hline
\end{tabular}

NA Not Active, S/ Selectivity Index; ${ }^{\text {a }}$ Stem back extract 
Table 3 Anti-echovirus activity of $M$. barteri fractions and subfractions

\begin{tabular}{|c|c|c|c|c|c|c|c|}
\hline \multirow[t]{2}{*}{$\mathrm{S} / \mathrm{N}$} & \multirow[t]{2}{*}{ Fractions } & \multirow{2}{*}{$\begin{array}{l}\mathrm{CC}_{50} \\
(\mu \mathrm{g} / \mathrm{mL})\end{array}$} & \multicolumn{3}{|c|}{$\mathrm{IC}_{50}(\mu \mathrm{g} / \mathrm{mL})$} & \multicolumn{2}{|l|}{$\mathrm{SI}$} \\
\hline & & & E7 & E13 & E19 & E7 & E19 \\
\hline 1 & Hexane & 24.9 & 0.44 & NA & 0.31 & 57.96 & 83.85 \\
\hline 2 & DCM & 0.18 & $7.54^{*} 10^{-6}$ & NA & $1.75^{*} 10^{-6}$ & $19,865.54$ & 8581.24 \\
\hline 3 & DCMA & 2.97 & 0.09 & NA & 0.54 & 33.82 & 5.50 \\
\hline 4 & $\mathrm{DCMB}$ & 0.89 & 0.03 & NA & 0.05 & 28.21 & 16.38 \\
\hline 5 & DCMC & 0.63 & NA & NA & 0.01 & - & 54.59 \\
\hline 6 & DCMD & 1.31 & $4.80^{*} 10^{-3}$ & NA & 0.01 & 247.70 & 246.1 \\
\hline 7 & DCME & 0.47 & 0.02 & NA & 0.01 & 24.23 & 44.09 \\
\hline 8 & DCMF & 24.35 & 1.61 & NA & 1.82 & 15.13 & 13.36 \\
\hline 9 & EtOAc & 2.87 & NA & NA & NA & - & NA \\
\hline 10 & Aqueous & 3.061 & NA & NA & NA & - & NA \\
\hline
\end{tabular}

NA Not Active, S/ Selectivity Index

\section{Discussion}

Enteroviruses have continued to pose a great burden to global health. Its faecal-oral route of transmission has enhanced the spread of these infectious agents, especially in developing nations, where there is poor sanitation and hygiene. Since the indigenes of these low and middle-income countries utilise medicinal plants to treat diseases caused by viruses, it is therefore imperative to investigate the antiviral potentials of indigenous medicinal plants.

In this study, 27 plant extracts selected from Nigerian ethnobotany were screened for their anti-enteroviral activity and we identified ten extracts with potent inhibitory activity against E7 and E19. Generally, the cytotoxic and anti-echovirus activities of all the extracts, partitioned or VLC fractions in this work were observed to be concentration dependent. The leaf extract of Macaranga barteri demonstrated the highest cytotoxic activity $\left(\mathrm{CC}_{50}=0.27 \mu \mathrm{g} / \mathrm{mL}\right)$, antiviral activity $\left(\mathrm{IC}_{50}=0.028 \mathrm{ng} / \mathrm{mL}\right.$ on E7; $0.00167 \mathrm{ng} / \mathrm{mL}$ on E19) and selectivity index (SI = 7971 on E7; 130,177.50 on E19). It was observed that the cytotoxicity evaluation of the extracts seemed to correspond directly to their anti-echovirus activities, a finding similar to our earlier result [15]. Ipomoea asarifolia leaf extract also showed potent antiviral activity against E7 $\left(\mathrm{IC}_{50}=0.0025 \mu \mathrm{g} / \mathrm{mL}\right)$ with a high selectivity index $(\mathrm{SI}=35,004)$ but was inactive against E19. Other plants with potent antiviral activity encountered in this study include Mondia whitei, Ageratum conyzoides and Terminalia ivorensis.

The most active plant extract, M. barteri was subjected to liquid-liquid partitioning and the DCM fraction showed the highest cytotoxicity $\left(\mathrm{CC}_{50}=0.18 \mu \mathrm{g} / \mathrm{mL}\right)$ and anti-echovirus activity $\left(\mathrm{IC}_{50}=0.0075 \mathrm{ng} / \mathrm{mL}\right.$ on E7; $0.0175 \mathrm{ng} / \mathrm{mL}$ on E19) with very high selectivity index ( $\mathrm{SI}=19,896.54$ on E7; 8581.24 on E19). Thus, it is safe to state that the anti-enteroviral property of $M$. barteri lies majorly in the moderately polar DCM fraction. The DCM fraction of some Macaranga species have been shown to be responsible for various bioactivity observed in the genus, especially against bacteria, cancer cells and Plasmodium falciparum [16, 17]. Fractionation of the DCM fraction using VLC led to a reduction in both the cytotoxic and antiviral activity (Table 3 ). This suggests the possibility of synergistic effect in the DCM partitioned fraction, prior to VLC fractionation.

Macaranga barteri, the most active of the 11 crude extracts, belongs to the family Euphorbiaceae, and it is used in Nigeria ethnomedicine as vermifuge and to treat dysentery (a gastroenteric infection) which could be caused by virus, bacteria or parasitic worm infections [18]. Therefore, the anti-enteroviral activity demonstrated by $M$. barteri in this study could justify the ethnomedicinal use of this plant in Nigeria. In addition, antimicrobial activity has been identified and generally implicated in the genus Macaranga [19]. An earlier research by Cos and co-workers reported that the leaves extract of another member of the Macaranga genus, M. kilimandscharica displayed high anti-measles activity, alongside a potent antiviral activity against Herpex simplex type 1 and Coxsackie viruses [20].

On spraying the most active sub-fraction with aluminium chloride, yellow spots were observed which indicated the presence of flavonoids. Flavonoids (especially prenylated flavonoids) and stilbenes have been reported as the major constituents of Macaranga and are said to be most likely responsible for most of the bioactivities of this genus [16]. Also, a wide range of flavonoids has been shown to possess antiviral activities against a variety of RNA viruses such as poliovirus, sindbis virus, respiratory syncytial virus (RSV), and DNA virus such as herpes simplex virus (HSV) [21]. The proposed antiviral mechanisms of action of flavonoids include inhibition of viral polymerase and binding of viral nucleic acid or viral capsid proteins [15]. Previous HPLC profiling of the DCM extract of $M$. barteri leaves revealed 3,5-dicaffeoylquinic acid, acteoside, kampferol-7$O$-glucoside and bastadin-11 as its major constituents [17]. Kaempferol-7-O-glucoside is a flavonol glucoside which possessed potent antiviral activity against Herpes simplex virus (HSV) and HIV-1 [22]. 3,5-dicaffeoylquinic acid (DCQA) is a phenolic acid which has been reported as a good inhibitor of HIV integrase, an enzyme required for integration of viral DNA into cellular DNA. Its antioxidant and anti-inflammatory activities have also been reported [23]. The anti-infective activities (antiviral and antimicrobial) of 3,5-dicaffeoylquinic acid (DCQA), acteoside, kampferol-7-O-glucoside which had been reported in literature and are present in DCM partitioned fraction of $M$. barteri could support the anti-echovirus activity of $M$. barteri reported in this study. 
The relatively high selectivity of the $M$. barteri extract and fractions, especially the most active sub-fraction (SI $=274.70$ on E7; 246.10 on E19) could be attributed to minimal toxicity possessed by the supposedly constituted flavonoids since flavonoids are believed to possess minimal toxicity, being distributed in edible plants and beverages [15].

\section{Conclusion}

To summarize our findings, we have reported the antiviral activity of 26 medicinal plants selected from Nigerian flora against three serotypes of enteroviruses (E7, E13 and E19). Ten of the medicinal plant extracts exhibited potent antiviral activity against E7 and E19, with Macaranga barteri being the most active. In addition, the DCM fraction $M$. barteri displayed the most potent antiviral activity amongst the fractions. Further research is in progress to isolate and elucidate the bioactive components that may be responsible for the antiviral activity of this plant and to determine their mechanism of action. To the best of our knowledge, this is the first report of the antiviral activity of $M$. barteri and indicates that the ethnobotanical use of these drugs may provide some benefits in the treatment of infectious diseases, thereby warranting further investigation.

\section{Abbreviations}

$\mathrm{CC}_{50}$ : 50\% cytotoxic concentration; CPE: Cytopathic effect;

DCM: Dichloromethane; DMSO: Dimethlysulfoxide; E13: Echovirus 13; E19: Echovirus 19; E7: Echovirus 7; EtOAc: Ethyl acetate; FBS: Fetal bovine serum; FHI: Forestry herbarium Ibadan; $I_{50}$ : 50\% inhibition concentration; MNTC: Maximum non-toxic concentration; MTT: 3-(4,5-dimethythiazol-2-yl)2,5-diphenyl tetrazolium bromide; RD: Human rhabdomyosarcoma cells; SI: Selectivity index; $\mathrm{TCID}_{50}$ : 50\% tissue culture infective concentration; TMPS: Traditional medical practitioners; VLC: Vacuum liquid chromatography

\section{Acknowledgements}

We thank the staff of the WHO Polio Laboratory, Department of Virology, University of Ibadan for the assistance rendered during the course of this research and the staff of the Forest Research Institute of Nigeria (FRIN) for the authentication of plant materials.

\section{Authors' contributions}

$\mathrm{OOO}$ and TCF conceived and designed the experiments. PAS and TEA carried out the plant extraction. OOO, PAS and TEA performed the antiviral assays. AJA and TCF provided cell culture materials and viruses. TEA and PAS prepared the manuscript and it was reviewed by 000 . All authors read and approved the final version of the manuscript.

Ethics approval and consent to participate

Not applicable.

\section{Consent for publication}

Not applicable.

\section{Competing interests}

The authors declare that they have no competing interests.

\section{Publisher's Note}

Springer Nature remains neutral with regard to jurisdictional claims in published maps and institutional affiliations.

\section{Author details}

'Department of Pharmacognosy, Faculty of Pharmacy, University of Ibadan, Ibadan, Nigeria. ${ }^{2}$ Department of Pharmacognosy, Faculty of Pharmacy, Olabis Onabanjo University, Sagamu, Nigeria. ${ }^{3}$ Department of Microbiology, Ekiti State University, Ado-Ekiti, Nigeria. ${ }^{4}$ Department of Virology, College of Medicine, University of Ibadan, Ibadan, Nigeria.

Received: 27 April 2018 Accepted: 11 July 2018

Published online: 18 July 2018

\section{References}

1. Ogbole OO, Adeniji AJ, Ajaiyeoba EO, Adu FD. Anti-poliovirus activity of medicinal plants selected from the Nigerian ethno-medicine. Afr J Biotechnol. 2013;12(24):3878-83.

2. Ernst M, Saslis-Lagoudakis CH, Grace OM, Nilsson N, Simonsen HT, Horn JW, Rønsted N. Evolutionary prediction of medicinal properties in the genus Euphorbia L. Sci Rep. 2016;6:30531.

3. Katiyar C, Gupta A, Kanjilal S, Katiyar S. Drug discovery from plant sources: an integrated approach. Ayu. 2012;33(1):10-9.

4. Henkin JM, Sydara K, Xayvue M, Souliya O, Kinghorn AD, Burdette JE, Chen $W-L$, Elkington BG, Soejarto DD. Revisiting the linkage between ethnomedical use and development of new medicines: a novel plant collection strategy towards the discovery of anticancer agents. J Med Plant Res. 2017;11(40):621.

5. Jain S, Patel B, Bhatt GC. Enteroviral encephalitis in children: clinical features, pathophysiology, and treatment advances. Pathog Glob Health. 2014;108(5): 216-22.

6. Haaheim LR, Pattison JR, Whitley RJ. A practical guide to clinical virology. Chapter 8: Australia: Wiley; 2002. p. 55-60.

7. Abedi GR, Watson JT, Pham H, Nix WA, Oberste MS, Gerber SI. Enterovirus and human parechovirus surveillance-United States, 2009-2013. MMWR Morb Mortal Wkly Rep. 2015;64(34):940-3.

8. Abzug MJ. The enteroviruses: problems in need of treatments. J Infect. 2014; 68:S108-14.

9. Linden Lvd WKC, van Kuppeveld FJ. Replication and inhibitors of enteroviruses and parechoviruses. Viruses. 2015;7(8):4529-62.

10. Carter JB, Saunders VA. Virology: principles and applications. Anti-viral Drugs. 2007;25:315-50

11. Jassim S, Naji MA. Novel antiviral agents: a medicinal plant perspective. J Appl Microbiol. 2003;95(3):412-27.

12. Ogbole O, Adeniji J, Ajaiyeoba E, Kamdem R, Choudhary M. Anthraquinones and triterpenoids from Senna siamea (Fabaceae) Lam inhibit poliovirus activity. Afr J Microbiol Res. 2014;8(31):2955-63.

13. Mosmann T. Rapid colorimetric assay for cellular growth and survival: application to proliferation and cytotoxicity assays. J Immunol Methods. 1983;65(1-2):55-63.

14. Lin YJ, Chang YC, Hsiao NW, Hsieh JL, Wang CY, Kung SH, Tsai FJ, Lan YC, Lin CW. Fisetin and rutin as 3 C protease inhibitors of enterovirus A71. J Virol Methods. 2012;182:93-8

15. Ogbole OO, Ajaiyeoba EO, Adeniji JA, Kamdem SR, Sajan S, Muhammad IC. Bioassay-guided isolation of poliovirus-inhibiting constituents from Zephyranthes candida. Pharm Biol. 2015;53(6):882-7.

16. Magadula JJ. Phytochemistry and pharmacology of the genus Macaranga: a review. J Med Plants Res. 2014;8(12):489-503.

17. Ogbole $\mathrm{OO}$, Segun PA, Adeniji AJ. In vitro cytotoxic activity of medicinal plants from Nigeria ethnomedicine on rhabdomyosarcoma cancer cell line and HPLC analysis of active extracts. BMC Complement Altern Med. 2017;17(1):494.

18. Segun PA, Ogbole OO, Ajaiyeoba EO. Medicinal plants used in the management of cancer among the ljebus of Southwestern Nigeria. J Herb Med. 2018 In Press, Accepted Manuscript

19. Yang D-S, Peng W-B, Yang Y-P, Liu K-C, Li X-L, Xiao W-L. CytotoxiC prenylated flavonoids from Macaranga indica. Fitoterapia. 2015;103:187-91.

20. Cos P, Hermans N, De Bruyne Y, Apers S, Sindambiwe JB, Vanden BB, Pieters L, Vlietinck AJ. Further evaluation of Rwandan medicinal plant extracts for their antimicrobial and antiviral activities. J Ethnopharmocol. 2002;79:155-63.

21. Middleton JE, Kandaswami C, Theoharides TC. The effects of plant flavonoids on mammalian cells: implications for inflammation, heart disease, and cancer. Pharmacol Rev. 2000:52:673-751.

22. Behbahani M, Sayedipour S, Pourazar A, Shanehsazzadeh M. In vitro antiHIV-1 activities of kaempferol and kaempferol-7-O-glucoside isolated from Securigera securidaca. Res Pharm Sci. 2014;9(6):463. 
23. Hong S, Joo T, Jhoo J-W. Antioxidant and anti-inflammatory activities of 3,5dicaffeoylquinic acid isolated from Ligularia fischeri leaves. Food Sci Biotechnol. 2015;24(1):257-63.

24. Adesanya SA, Olugbode TA, Odebiyi OO, Aladesanmi JA. Antibacterial alkaloids in Crinum jagus. Int J Pharmacogn. 1992;4:303-7.

25. Sabiu S, Garuba T, Sunmonu T, Ajani E, Sulyman A, Nurian I, Balogun A. Indomethacin-induced gastric ulceration in rats: protective roles of Spondias mombin and Ficus exasperata. Toxicol Rep. 2015;2:261-7.

26. Erharuyi O, Falodun A, Langer P. Medicinal uses, phytochemistry and pharmacology of Picralima nitida (Apocynaceae) in tropical diseases: A review. Asian Pacific journal of tropical medicine. 2014;7(1):1-8.

27. Zabri H, Kodjo C, Benie A, Bekro JM, Bekro YA. Phytochemical screening and determination of flavonoids in Secamone afzelii (Asclepiadaceae) extracts. Afr J Pure Appl Chem. 2008;2(8):080-2.

28. Okunade AL. Ageratum conyzoides L. (Asteraceae). Fitoterapia. 2002;73:1-16.

29. Paul S, Chakraborty S, Mukherjee A, Kundu R. Evaluation of cytotoxicity and DNA damaging activity of three plant extracts on cervical cancer cell lines. Int J Pharm Sci Rev Res. 2015;31(1):183-9.

30. Ponou BK, Teponno RB, Ricciutelli M, Nguelefack TB, Quassinti L, Bramucc M, Lupidi G, Barboni L, Tapondjou LA. Novel 3-Oxo-and 3, 24-Dinor-2, 4secooleanane-type triterpenes from Terminalia ivorensis A. Chev. Chem Biodivers. 2011;8(7):1301-9.

31. Kuete V, Tabopda TK, Ngameni B, Nana F, Tshikalange TE, Ngadjui BT. Antimycobacterial, antibacterial and antifungal activities of Terminalia superba (Combretaceae). S Afr J Bot. 2010;76(1):125-31.

32. Meira M, Silva EP, David JM, David JP. Review of the genus Ipomea: traditional uses, chemistry and biological activities. Rev Bras. 2012;22(3)

33. Olugbuyiro JA, Akinbohun OF. In vitro activity of Bryophyllum pinnatum and Detarium microcarpum plants against Mycobacterium tuberculosis and other bacteria. Nat Prod Res Bull. 2012;1:12-8.

34. Olorunnisola OS, Afolayan AJ, Adetutu A. Sub-chronic administration of methanolic whole fruit extract of Lagenaria breviflora (Benth.) Roberty induces mild toxicity in rats. Pharmacogn Mag. 2015;11(Suppl 4):S516-21.

35. Onoagbe IO, Attah V, Luther MM, Esekheigbe A. Hypoglyccemic and antidiabetic effects of Morinda lucida and Tetracera alnifolia in normal streptozotocin-induced diabetic rabbits. West Afr J Biol Sci. 1999;9:1-8.

36. Mulholland DA, Langat MK, Crouch NR, Coley HM, Mutambi EM, Nuzillard $\mathrm{J}-\mathrm{M}$. Cembranolides from the stem bark of the southern African medicinal plant, Croton gratissimus (Euphorbiaceae). Phytochemistry. 2010;71(11-12): 1381-6.

37. Ogbole OO, Segun PA, Fasinu PS. Antimicrobial and antiprotozoal activities of twenty-four Nigerian medicinal plant extracts. S Afr J Bot. 2018;117:240-6

38. Achenbach $\mathrm{H}$, Waibel $\mathrm{R}$, Nkunya $\mathrm{MH}$, Weenen $\mathrm{H}$. Antimalarial compounds from Hoslundia opposita. Phytochemistry. 1992;31(11):3781-4.

39. Adaramoye O, Erguen B, Oyebode O, Nitzsche B, Höpfner M, Jung K, Rabien A. Antioxidant, antiangiogenic and antiproliferative activities of root methanol extract of Calliandra portoricensis in human prostate cancer cells. J Integr Med. 2015;13(3):185-93.

40. John TA, Onabanjo A. Gastroprotective effects of an aqueous extract of Entandrophragma utile bark in experimental ethanol-induced peptic ulceration in mice and rats. J Ethnopharmacol. 1990;29(1):87-93.

41. Ahmad H, Sehgal S, Mishra A, Gupta R. Mimosa pudica L. (Laajvanti): an overview. Pharmacogn Rev. 2012;6(12):115-30.

42. Rawat A, Mehrotra S, Tripathi S, Shome U. Hepatoprotective activity of Boerhaavia diffusa L. roots - a popular Indian ethnomedicine. J Ethnopharmacol. 1997;56(1):61-6.

43. Watcho PP, Kamtchouing S, Sokeng PF, Noundipa PF, Tantchou J, Essame JL, Koueta N. Reversible antispermatogenic and antifertility activities of Mondia whitei L. in male white albino. Phytother Res. 2001; 15(1):29.

44. Imaga N, Gbenle G, Okochi V, Adenekan S, Edeoghon S, Kehinde M, Bamiro S, Ajiboye A, Obinna A. Antisickling and toxicological profiles of leaf and stem of Parquetina nigrescens L. J Med Plants Res. 2010;4(8):639-43.

45. Williams LA, Rosner H, Levy HG, Barton EN. A critical review of the therapeutic potential of dibenzyl trisulphide isolated from Petiveria alliacea $L$ (guinea hen weed, anamu). West Indian Med J. 2007:56

46. Oyemitan IA, Olayera OA, Alai A, Abass LA, Elusiyan CA, Oyedeji AO, Akanmu MA. Psychoneuropharmacological activities and chemical composition of essential oil of fresh fruits of Piper guineense (Piperaceae) in mice. J Ethnopharmocol. 2015;166:240-9.
47. Iqbal M, Gnanaraj C. Eleusine indica L. possesses antioxidant activity and precludes carbon tetrachloride $\left(\mathrm{CCl}_{4}\right)$-mediated oxidative hepatic damage in rats. Environ Health Prev Med. 2012;17(4):307-15.

48. Amos S, Abbah J, Chindo B, Edmond I, Binda L, Adzu B, Buhari S, Odutola AA, Wambebe C, Gamaniel K. Neuropharmacological effects of the aqueous extract ot Nauclea latifolia root bark i rats and mice. J Ethnopharmocol. 2005; 97:53-7.

49. Abena AA, Diatewa M, Gakosso G, Gbeassor M, Hondi-Assah T, Ouamba JM. Analgesic, antipyretic and anti-inflammatory effects of essential oil of Lippia multiflora. Fitoterapia. 2003;74(3):231-6.
Ready to submit your research? Choose BMC and benefit from:

- fast, convenient online submission

- thorough peer review by experienced researchers in your field

- rapid publication on acceptance

- support for research data, including large and complex data types

- gold Open Access which fosters wider collaboration and increased citations

- maximum visibility for your research: over $100 \mathrm{M}$ website views per year

At BMC, research is always in progress.

Learn more biomedcentral.com/submissions 